\title{
Pendapatan Premi, Rasio Hasil Investasi, Laba, Klaim dan Risk Based Capital Perusahaan Asuransi Kerugian di Indonesia
}

\author{
Richard Alamsyah ${ }^{1}$, Adi Wiratno ${ }^{2}$ \\ ${ }^{1}$ Universitas Pancasila, Jl. Srengseng Sawah, Jagakarsa, Jakarta Selatan, 12640 \\ ${ }^{2}$ Universitas Jenderal Soedriman, Jl. HR. Boenyamin 708, Grendeng, Purwokerto Utara, Jawa Tengah 53122
}

\section{INFO ARTIKEL \\ JEL Classsification: \\ G32 \\ G22}

Keywords:

premium income,

investment income ratio,

profitability, claims and

risk based capital.

\begin{abstract}
Research in the insurance industry has not been widely studied. This study aims to premium income, investment claims ratio and stock-based risk to risk-based capital of insurance companies. This study uses empirical data derived from financial statements with a sample of 14 companies for the period 2011-2015, using purposive sampling. The method of analysis used is multiple regression. Based on the test results, the ratio of Risk and Capital Risk Risk (RBC). However, profitability and premium income do not affect Risk Based Capital (RBC) variable. Future research using a sample of insurance companies can test other financial aspects in order to obtain empirical evidence related to determinants of financial performance for the insurance services industry.
\end{abstract}

\begin{abstract}
A B S T R A K
Riset di bidang industri asuransi belum banyak dikaji. Penelitian ini bertujuan untuk pendapatan premi, rasio klaim investasi dan risiko berbasis saham terhadap risk based capital perusahaan asuransi. Penelitian ini menggunakan data empiris yang berasal dari laporan keuangan dengan sampel 14 perusahaan untuk periode 2011-2015, dengan menggunakan purposive sampling. Metode analisis yang digunakan adalah regresi berganda. Berdasarkan hasil pengujian, rasio Risk and Capital Risk Risk (RBC). Namun, profitabilitas dan pendapatan premi tidak mempengaruhi variabel Risk Based Capital (RBC). Penelitian mendatang dengan menggunakan sampel perusahaan asuransi dapat menguji aspek-aspek keuangan lain agar dapat diperoleh bukti empiris terkait faktor-faktor penentu kinerja keuangan untuk industri jasa asuransi.
\end{abstract}

\section{Pendahuluan}

Selama beberapa tahun belakangan ini, perkembangan asuransi di Indonesia menunjukkan angka kemajuan yang cukup baik. Perusahaan asuransi menunjukkan geliat pertumbuhan di dalam usaha yang mereka jalankan, yang mana semakin hari semakin banyak nasabah yang mengunakan layanan asuransi di dalam kehidupan mereka.
Kesadaran masyarakat akan pentingnya sebuah perlindungan atas berbagai macam risiko yang bisa terjadi dan menimpa diri mereka sewaktuwaktu adalah salah satu penyebab tingginya jumlah pengguna asuransi belakangan ini. Hal ini tentu saja menjadi sebuah keuntungan tersendiri bagi perusahaan asuransi yang menyediakan layanan asuransi, di mana akan semakin luas

*Email Korespondensi: ${ }^{1}$ alamsyahrichard@gmail.com, ${ }^{2}$ adiwiratno08@yahoo.com 
pasar yang bisa diolah dan dijadikan sebagai sasaran penjualan produk yang mereka miliki.

Pemerintah selaku regulator dalam rangka menjaga stabilitas kondisi perkembangan yang terjadi dalam industri perasuransian nasional, melakukan penyesuaian secara menyeluruh terhadap ketentuan mengenai kesehatan keuangan Perusahaan Asuransi dan Perusahaan Reasuransi sebagaimana diatur dalam Keputusan Menteri Keuangan Nomor 53/PMK.10/2012. Dan dalam rangka lebih menjamin stabilitas kondisi keuangan perusahaan asuransi, maka pengaturan mengenai kesehatan keuangan perusahaan asuransi dalam Keputusan Menteri Keuangan Nomor 53/PMK.10/2012. Dan untuk mengatur tentang solvabilitas perusahaan asuransi dikeluarkan Peraturan Ketua Badan Pengawas Pasar Modal dan Lembaga Keuangan Nomor PER-08/BL/2012 tentang Pedoman Perhitungan Batas Tingkat Solvabilitas Minimum (Risk Based Capital) bagi Perusahaan Asuransi dan Perusahaan Reasuransi.

Hasil penelitian dari Georgios Pitselis (2006) menemukan bahwa solvabilitas pengawasan juga harus memperhitungkan setiap akun tidak hanya faktor-faktor endogen (manajemen yang baik, estimasi yang baik pada cadangan teknis, dll), tetapi juga faktor-faktor eksogen (tingkat pengembalian, tingkat pengangguran dil) serta keunikan asuransi pasar masing-masing negara. Hasil penelitian dari Martin dan Scott (1998) menemukan bahwa sistem RBC bagaimanapun bermanfaat bila digunakan oleh regulator dalam kombinasi dengan sistem screening yang lebih akurat, atau bahwa politik tekanan terhadap peningkatan RBC menyebabkan akurasi formula $\mathrm{RBC}$ relatif rendah.

Solvabilitas dalam perusahaan asuransi berbeda dengan solvabilitas pada perusahaan manufaktur maupun perusahaan dagang. Pada perusahaan manufaktur dan perusahaan dagang menurut prawoto (2006) solvabilitas adalah kemampuan untuk membayar kewajiban tak lancar (kewajiban jangka panjang), baik pokok maupun bunganya. Kemampuan untuk membayar kewajiban tak lancar bergantung pada kemapuan perusahaan dalam menghasilkan laba karena cicilan hutang pokok maupun bunganya menurut kelaziman dibayar dengan dana kas, dan besarnya dana kas sangat ditentukan oleh besarnya laba yang masuk perusahaan dalam bentuk uang kas. Menurut Kuswadi (2006) Nilai rasio-rasio solvabilitas yang baik adalah kecil sehingga dapat menggambarkan bahwa beban kewajiban perusahaan tidak terlalu berat. Dengan demikian semakin kecil angka rasio semakin tinggi solvabilitas perusahaan. Rasio yang digunakan untuk mengukur solvabilitas adalah rasio kewajiban atas total aktiva, rasio kewajiban atas total ekuitas, dan rasio kewajiban jangka panjang atas kapitalisasi.

Sedangkan solvabilitas perusahaan asuransi diatur oleh Pemerintah dalam rangka menyesuaikan dengan perkembangan yang terjadi dalam industri perasuransian nasional, melakukan penyesuaian secara menyeluruh terhadap ketentuan mengenai Kesehatan Keuangan Perusahaan Asuransi Dan Perusahaan Reasuransi sebagaimana diatur dalam Keputusan Menteri Keuangan Nomor 53/PMK.10/2012. Dalam Peraturan Ketua Bapepam LK PER02/BL/2008 tentang Pedoman Perhitungan Batas Tingkat Solvabilitas Minimum (Risk Based Capital) bagi Perusahaan Asuransi dan Perusahaan Reasuransi Solvabilitas perusahaan asuransi yang dikenal dengan Risk Based Capital atau dalam istilah bahasa Indonesia yaitu Batas Tingkat Solvabilitas Minimum adalah jumlah minimum tingkat solvabilitas yang harus dimiliki perusahaan asuransi atau perusahaan reasuransi, yaitu sebesar jumlah dana yang dibutuhkan untuk menutup risiko kerugian yang mungkin timbul sebagai akibat dari deviasi dalam pengelolaan kekayaan dan kewajiban.

Dalam Keputusan Menteri Keuangan Nomor 53/PMK.10/2012 Pasal 2 ayat 1 yaitu Perusahaan Asuransi dan Perusahaan Reasuransi setiap saat wajib memenuhi tingkat solvabilitas paling sedikit $120 \%$ (seratus dua puluh per seratus) dari risiko kerugian yang mungkin timbul sebagai akibat dari deviasi dalam pengelolaan kekayaan dan kewajiban. 
Risiko kerugian yang mungkin timbul sebagai akibat dari deviasi dalam pengelolaan kekayaan dan kewajiban yang dimaksud adalah : 1) kegagalan pengelolaan kekayaan, ketidakseimbangan antara proyeksi arus kekayaan dan kewajiban; 2) ketidak-seimbangan antara nilai kekayaan dan kewajiban dalam setiap jenis mata uang; 3) perbedaan antara beban klaim yang terjadi dan beban klaim yang diperkirakan; 4) ketidak-cukupan premi akibat perbedaan hasil investasi yang diasumsikan dalam penetapan premi dengan hasil investasi yang diperoleh; 5) ketidak-mampuan pihak reasuradur untuk memenuhi kewajiban membayar klaim.

Tujuan pemerintah menerapkan metode Risk Based Capital adalah selain untuk melindungi kepentingan masyarakat sebagai nasabah asuransi juga dalam rangka menyesuaikan dengan perkembangan yang terjadi dalam industri perasuransian nasional. Pemerintah telah memberikan payung hukum untuk melindungi kepentingan nasabah perusahaan asuransi dengan menetapkan Risk Based Capital.
Sehingga, diharapkan perusahaan asuransi memiliki kekuatan modal yang cukup dan menghindarkan risiko merugikan nasabahnya dalam hal terjadi masalah atau kerugian sebagai akibat dari deviasi dalam pengelolaan kekayaan dan kewajiban.

Hasil penelitian dari Merawati (2002) menemukan bahwa Nilai Risk Based Capital yang diperoleh oleh perusahaan tidak dapat hanya diartikan dengan besar kecilnya angka. Memang nilai Risk Based Capital yang rendah mengisyaratkan bahwa perusahaan asuransi tersebut mempunyai kinerja yang kurang baik. Namun nilai Risk Based Capital yang sangat tinggipun belum tentu menunjukkan bahwa perusahaan tersebut adalah yang terbaik. Realitanya nilai Risk Based Capital sebagian besar perusahaan asuransi jauh lebih tinggi diatas ketentuan yang berlaku yang hanya sebesar 120\%. Sebagai contoh Tabel 1 dibawah ini yaitu 10 Perusahaan Asuransi Kerugian Swasta Nasional Yang Mempublikasi Laporan Keuangan Di Media Cetak Dengan Tingkat Risk Based Capital Tertinggi 2011-2015.

Tabel 1. 10 Perusahaan Asuransi Kerugian Swasta Nasional Yang Mempublikasi Laporan Keuangan Di Media Cetak Dengan Tingkat Risk Based Capital Tertinggi 2011-2015

\begin{tabular}{|c|c|c|c|c|c|}
\hline Nama Perusahaan & 2011 & 2012 & 2013 & 2014 & 2015 \\
\hline 1 PT. ASURANSI UMUM VIDEI & $1175,80 \%$ & $810,60 \%$ & $1560,30 \%$ & $1090,70 \%$ & $855,00 \%$ \\
\hline 2 PT. ASURANSI ARTHARINDO & $581,62 \%$ & $987,00 \%$ & $1178,00 \%$ & $945,00 \%$ & $704,00 \%$ \\
\hline 3 PT. ASURANSI BHAKTI BHAYANGKARA & 895,0 & $0 \%$ & $648,00 \%$ & $448,00 \%$ & $405,00 \%$ \\
\hline 4 PT. ASURANSI ASEI INDONESIA & $782,00 \%$ & $542,39 \%$ & $512,33 \%$ & $132,91 \%$ & $169,00 \%$ \\
\hline 5 PT. TUGU PRATAMA INDONESIA & 335,00 & 345 & 533 , & $394,10 \%$ & $374,00 \%$ \\
\hline 6 PT. SOMPO JAPAN NIF & 427 , & 290 & $0 \%$ & $206,00 \%$ & $140,00 \%$ \\
\hline 7 PT. ASURANSI SINARMAS & $328,00 \%$ & $300,00 \%$ & $328,59 \%$ & $338,25 \%$ & $359,00 \%$ \\
\hline 8 PT. ASURANSI SAMSUNG TUGU & & & & & $265,00 \%$ \\
\hline 9 PT. ASURANSI MEGA PRATAMA & $286,67 \%$ & $195,45 \%$ & $199,79 \%$ & $388,05 \%$ & $296,00 \%$ \\
\hline 10 PT. ASURANSI TOKIO MARINE INDONESIA & $236,00 \%$ & $248,00 \%$ & $244,00 \%$ & $242,00 \%$ & $291,00 \%$ \\
\hline
\end{tabular}

Sumber: Otoritas Jasa keuangan

Sifat bisnis asuransi membutuhkan investasi uang yang besar. Sumber dana-dana perusahaan asuransi untuk membayar kerugian-kerugian adalah dari modal yang telah disetor, surplus, dan premi yang telah dibayar dimuka untuk jasajasa yang diberikan. Pengelolaan bisnis yang baik menghendaki dana-dana itu di investasikan dengan aman dan menguntungkan. Orang-orang yang ahli dalam analisis investasi sangat penting bagi operasi perusahaan asuransi. Asuransi adalah lembaga keuangan yang sangat penting dan dengan demikian mempunyai pengaruh besar dalam perekonomian. Tabel 2 dibawah ini yaitu gambaran singkat laporan keuangan asuransi kerugian gabungan di indonesia periode 2011-2015. 
Table 2. Gambaran Singkat Kinerja Perusahaan Asuransi Kerugian Gabungan di Indonesia Periode 2011-2015

(Dalam Milyaran Rupiah kecuali RBC)

\begin{tabular}{lccccc}
\hline \multirow{2}{*}{ Keterangan } & \multicolumn{5}{c}{ Tahun } \\
\cline { 2 - 6 } & 2011 & 2012 & 2013 & 2014 & 2015 \\
\hline Premi Bruto & 38,83 & 44,91 & 53,19 & 54,67 & 57,612 \\
Investasi & 42,4 & 51,44 & 61,24 & 63,61 & 66,147 \\
Laba Bruto & 4,409 & 4,528 & 3,657 & 6,518 & 7,282 \\
Klaim Bruto & 15,05 & 20,19 & 21,59 & 27,93 & 32,514 \\
RBC & $244,79 \%$ & $289,90 \%$ & $275,16 \%$ & $306,11 \%$ & $254,10 \%$ \\
\hline
\end{tabular}

Sumber: Otoritas Jasa keuangan

Berdasarkan data tersebut secara keseluruhan premi dan investasi mengalami kenaikan setiap tahunnya akan tetapi tidak demikian pada nilai Risk Based Capital pada masing-masing perusahaan yang mengalami fluktuasi hal tersebut terlihat pada Table 1.2. hal tersebut menunjukan bahwa premi, investasi, klaim diduga tidak berpengaruh pada tinggi dan rendahnya Risk Based Capital. Sedangkan premi, investasi, dan klaim merupakan komponen utama dalam perhitungan Risk Based Capital.

Berdasarkan data tersebut secara keseluruhan Klaim mengalami kenaikan setiap tahunnya akan tetapi tidak demikian pada nilai Risk Based Capital pada masing-masing perusahaan sebagaimana di tampilkan pada Table 2 hal tersebut menunjukan bahwa Klaim diduga tidak berpengaruh pada tinggi dan rendahnya Risk Based Capital. Sedangkan pada perhitungan Risk Based Capital perbedaan antara beban klaim yang terjadi diperkirakan menjadi salah satu komponen utama.

\section{Telaah Teori dan Pengembangan Hipotesis}

Terdapat sejumlah penelitian sejenis yang berhubungan dengan risk based capital perusahaan. Dalam penelitian Kurniawan (2010) melakukan analisis pengaruh pendapatan premi, rasio hasil investasi dan klaim terhadap risk based capital pada perusahaan asuransi dan reasuransi. Penelitian ini menyimpulkan bahwa adanya pengaruh yang signifikan dari pendapatan premi dan rasio hasil investasi terhadap risk based capital.

Pada tahun 2013 Reni marlina dan Dwi Puryanti dalam jurnal The Influence of Risk Based Capital to Profitability in Jasindo Insurance Company melakukan analisis profitabilitas dari risk based capital Jasindo Insurance Company selama periode 20072010. Penelitian ini menggunakan simple linear regression dan pearson correlation dan return on assets (ROA) dan return on equity (ROE) sebagai indikator dari profitabilitas. Penelitian ini menunjukan bahwa risk based capital tidak memiliki pengaruh terhadap profitabilitas pada perusahaan Jasindo Insurance

Dalam penelitian Kirmizi \& Agus (2011) dalam jurnal Pengaruh Pertumbuhan Modal dan Aset Terhadap Rasio Risk Based Capital (RBC), Pertumbuhan Premi Neto dan Profitabilitas perusahaan asuransi umum di Indonesia. Dalam penelitian ini menyimpulkan bahwa penambahan modal dalam perusahaan secara umum tidak dimanfaatkan secara produktif dan optimal dalam meningkatkan perolehan premi. Begitu pula dengan rasio risk based capital secara spesifik tidak berpengaruh dalam mendorong perolehan premi dan peningkatan laba. Sementara disisi lain, pertumbuhan aset berperan positif dalam meningkatkan perolehan premi. Secara umum pertumbuhan premi neto perusahaan meningkat, namun tidak berpengaruh signifikan terhadap ROE. 
Sementara itu, dalam penelitian Witono $\mathrm{Ng}$ (2003) dalam jurnal Analisis kinerja perusahaanperusahaan asuransi di Indonesia dengan metode risk based capital. dalam penelitian ini menyimpulkan bahwa pendapatan premi dan beban klaim tidak mempunyai hubungan yang kuat dengan risk based capital, bahwa besarnya kontribusi pendapatan premi dan klaim terhadap variasi (naik turunnya) risk based capital sangat kecil dan tidak signifikan.

Dalam penelitian Subiakto Soekarno \& Dhinda (2009) dalam jurnal Analysis of Financial Ratio to Distinguish Indonesia Joint Venture General Insurance Company Performance Using Discriminant Analysis. Penelitian ini menenujukan risk based capital, technical reserve to investment ratio, debt ratio, return on equity, expense ratio berpengaruh terhadap kinerja keuangan perushaan asuransi.

\section{Metode}

Penelitian ini menggunakan metode penelitian kuantitatif yaitu suatu pendekatan penelitian yang bersifat objektif, mencakup pengumpulan dan analisis data kuantitatif serta menggunakan metode pengujian statistik. Analisis yang digunakan dalam penelitian ini yaitu analisis regresi berganda untuk menguji pendapatan premi, rasio hasil investasi, laba dan klaim terhadap risk based capital. Tahun penelitian yang digunakan adalah 2011 sampai dengan 2015 dengan objek penelitiannya yaitu perusahaan asuransi.

Variabel yang digunakan dalam penelitian ini adalah ada 2 variabel yaitu variabel independen dan dependen. Variabel independen terdiri dari pendapatan premi, rasio hasil investasi, laba dan klaim, sedangkan variabel dependennya adalah risk based capital. Rincian keterangan dari tiap variabel dapat dilihat dari tabel 3 .

Tabel 3. Variabel dan Pengukuran

\begin{tabular}{ll}
\hline \multicolumn{1}{c}{ Variable } & \multicolumn{1}{c}{ Keterangan dan Skala Pengukuran } \\
\hline Pendapatan Premi & $\begin{array}{l}\text { Yaitu besarnya premi bruto yang dihasilkan perusahaan yang diukur } \\
\text { berdasarkan skala nominal. }\end{array}$ \\
Rasio Hasil Investasi & $\begin{array}{l}\text { Yaitu besarnya hasil investasi dibagi dengan total investasi perusahaan } \\
\text { yang diukur berdasarkan skala rasio. }\end{array}$ \\
Klaim & Yaitu besarnya Klaim Bruto yang dibebankan perusahaan yang diukur \\
& berdasarkan skala nominal. \\
Laba & Yaitu nilai prestasi kesehatan keuangan suatu perusahaan dan kemampuan \\
& perusahaan dalam menjalankan kegiatan operasionalnya secara maksimal \\
& diukur berdasarkan skala nominal \\
& Yaitu dihitung dengan ketentuan Keputusan Menteri Keuangan Nomor \\
Risk Based Capital & M24/KMK.006/2003 dan Peraturan Ketua Badan Pengawas Pasar \\
& Modal dan Lembaga Keuangan Nomor : Per- 02/BL/2009 yang diukur \\
& berdasarkan skala rasio. \\
\hline
\end{tabular}

Data yang digunakan dalam penelitian ini merupakan data sekunder yang diperoleh dari laporan tahunan (annual report). Pengambilan sampel dalam penelitian ini menggunakan metode purposive sampling. Dengan metode purposive sampling, sampel dipilih atas dasar kesesuaian karakteristik sampel dengan kriteria pemilihan sampel yang ditentukan, yaitu: a) Perusahaan asuransi kerugian yang telah terdaftar di Otoritas Jasa Keuangan (OJK).

b) Menerbitkan laporan keuangan selama periode penelitian, yaitu dari tahun 2011 sampai dengan 2015 dan mempublikasikan baik di media cetak maupun di website perusahaan

c) Perusahaan asuransi kerugian swasta 
nasional yang memiliki tingkat risk based capital diatas $120 \%$

d) Perusahaan asuransi kerugian swasta nasional yang memiliki ekuitas diatas 500 miliar

Metode analisis data terlebih dahulu dilakukan uji normalitas untuk mengetahui kenormalan distribusi data. Uji normalitas data bertujuan untuk melihat apakah variabel independen, variabel dependen atau keduanya berdistribusi normal atau tidak. Uji normalitas dilakukan dengan analisa grafik, dengan dasar pengambilan keputusan adalah sebagai berikut:

a. Jika data menyebar di sekitar garis diagonal dan mengikuti arah garis diagonalnya, maka model regresi memenuhi asumsi normalitas.

b. Jika data menyebar jauh dari garis diagonal dan/atau tidak mengikuti arah garis diagonal, maka model regresi tidak memenuhi asumsi normalitas.

Kemudian dilakukan uji asumsi klasik untuk menguji apakah data yang digunakan mengandung pelanggaran asumsi klasik atau tidak. Uji asumsi klasik tersebut adalah sebagai berikut:
1. Uji Multikolinearitas

Multikolinearitas artinya terdapat korelasi yang signifikan di antara dua atau lebih variabel independen dalam suatu model regresi. Multikolinearitas terjadi jika nilai Variance Inflation Factor (VIF) melebihi nilai dari 10 (Hair et. Al. 1998). Hipotesis pengujian multikolinearitas : Ho ; tidak ada multikolinearitas, Ha ; ada multikolinearitas. Dasar pengambilan keputusan : Jika VIF>10, maka Ho ditolak (ada multikolinearitas) sedangkan jika $\mathrm{VIF}<10$, maka Ho gagal ditolak (tidak ada multikonearitas).

2. Uji Autokorelasi

Autokorelasi menunjukkan bahwa ada korelasi antara kesalahan (error) masa sekarang dengan kesalahan (error) periode sebelumnya dimana pada asumsi klasik hal ini tidak boleh terjadi. Permasalahan autokorelasi hanya relevan digunakan jika data yang dipakai adalah time series sedangkan untuk data cross-series tidak perlu dilakukan. Pengujian autokorelasi dapat dilakukan dengan Durbi Waston test. Hipotesis pengujian autokorelasi Ho : tidak ada autokorelasi dan Ha : ada autokorelasi.

Tabel 4. Dasar Pengambilan Keputusan

\begin{tabular}{lll}
\hline \multicolumn{1}{c}{ Kriteria } & \multicolumn{1}{c}{ Ho } & \multicolumn{1}{c}{ Keputusan } \\
\hline $0<\mathrm{DW}<\mathrm{dl}$ & Ditolak & Ada autokorelasi positif \\
$\mathrm{D} 1<\mathrm{DW}<\mathrm{du}$ & Tidak ada keputusan & Tidak ada keputusan \\
$4-\mathrm{dl}<\mathrm{DW}<4$ & Ditolak & Ada autokorelasi negative \\
$4-\mathrm{du}<\mathrm{DW}<4 \mathrm{dl}$ & Tidak ada keputusan & Tidak ada keputusan \\
$\mathrm{Du}<\mathrm{DW}<4-\mathrm{du}$ & Diterima & Tidak ada autokorelasi \\
\hline
\end{tabular}

3. Uji Heteroskedastisitas

Heteroskedastisitas menunjukkan bahwa varians dari setiap error bersifat heterogen berarti melanggar asumsi klasik yang mensyaratkan bahwa varians dari error harus bersifat homogen. Hipotesis pengujian heteroskedastisitas. Dasar pengambilan keputusan, jika signifikan $<0.05$, maka Ho ditolak (ada heteroskedastisitas), dan jika tidak signifikan $>0.05$, maka Ho gagal ditolak (tidak ada heteroskedasitas).

Uji Koefisien Determinasi (R2) digunakan untuk mengetahui keeratan hubungan antara variabel bebas dengan variabel terikat. Nilai R2 mempunyai interval antara 0 sampai 1 $(0 \leq \mathrm{R} 2 \geq 1)$. Semakin besar R2 (mendekati 1), maka semakin baik hasil untuk model regresi tersebut. Sebaliknya, semakin 
mendekati 0, maka variabel independen secara keseluruhan tidak dapat menjelaskan variabel dependen (Sulaiman, 2006).

Uji t, yaitu untuk menguji persamaan regresi ganda secara parsial, yaitu untuk mengetahui pengaruh masing-masing variabel bebas terhadap variabel terikat. Kriteria pengambilan keputusan, yaitu:

a) Bila hasil uji kurang dari nilai signifikan $($ Sig $\leq 0,05)$, maka Ha (hipotesis alternatif) diterima, ini menunjukkan terdapat pengaruh yang signifikan antara satu variabel independen terhadap variabel dependen.

b) Bila hasil uji lebih dari nilai signifikan (Sig $>$ 0,05), maka Ha (hipotesis alternatif) ditolak hal tersebut menunjukkan tidak terdapat pengaruh yang signifikan antara satu variabel independen terhadap variabel dependen

Berdasarkan hipotesa sebelumnya dilakukan suatu pengujian apakah perubahan dari variabel bebas mempengaruhi variabel tidak bebas. Untuk menguji seluruh hipotesis dalam penelitian ini adalah dengan menggunakan regresi berganda dimana persamaan yang dibentuk dirumuskan sebagai berikut:

Rumus:

$$
Y=\beta o+\beta 1 X 1+\beta 2 X 2+\beta 3 X 3+\beta 4 X 4 \varepsilon
$$

$$
\begin{array}{ll}
\text { Dimana: } & \\
\boldsymbol{\beta 0} & =\text { konstanta } \\
\boldsymbol{\beta 1}, \boldsymbol{\beta 2}, \boldsymbol{\beta 3} & =\text { koefisien regresi } \\
\mathbf{Y} & =\text { Risk Based Capital } \\
\mathbf{X 1} & =\text { Pendapatan Premi } \\
\mathbf{X 2} & =\text { Rasio Hasil Investasi } \\
\mathbf{X 3} & =\text { Laba } \\
\mathbf{X 4} & =\text { Klaim }
\end{array}
$$

\section{Hasil Penelitian dan Pembahasan}

Tujuan penelitian ini mengetahui bagaimana pengaruh variabel bebas pendapatan premi $\left(\mathrm{X}_{1}\right)$, rasio hasil investasi $\left(\mathrm{X}_{2}\right)$, Laba $\left(\mathrm{X}_{3}\right)$ dan klaim $\left(\mathrm{X}_{4}\right)$ terhadap variabel terikat RBC $(\mathrm{Y})$. Teknik analisis statistik model persamaan regresi ganda digunakan untuk mengetahui bagaimana pengaruh tersebut melalui pengujian hipotesis statistik. Model persamaan regresi ganda yang dihasilkan dengan pengujian hipotesis harus memenuhi asumsi statistik klasik. Dari model yang dihasilkan dan pengujian hipotesis, maaka selanjutnya dilakukan analisis dan pembahasan.

Didalam penelitian ini, uji normalitas digunakan untuk mengetahui sebaran data hasil observasi yang diperoleh dari tahun 2011 sampai dengan tahun 2015, dimana dapat diketahui Dari hasil uji statistik Kolmogorov-Smirnov dapat diketahui nilai signifikansi (Asymp. Sig.2-tailed) melebihi atau lebih besar $0,05(0,294>0,05)$, sehingga $\mathrm{H}_{0}$ diterima, yang berarti data residual berdistribusi normal.

Tabel 5. Uji Kolmogorov - Smirnov

\begin{tabular}{llr}
\hline & & Unstandardized Residual \\
\hline $\mathrm{N}$ & & 70 \\
Normal Parameters ${ }^{\mathrm{a}, \mathrm{b}}$ & Mean &, 0000000 \\
& Std. Deviation &, 85176010 \\
Most Extreme & Absolute &, 117 \\
Differences & Positive &, 117 \\
& Negative &,- 088 \\
Kolmogorov-Smirnov Z & &, 979 \\
Asymp. Sig. (2-tailed) & &, 294 \\
\hline
\end{tabular}


Jika residual berasal dari distribusi normal, nilai-nilai sebaran data akan terletak disekitar garis lurus. Terlihat bahwa sebaran data pada chart diatas dikatakan tersebar di sekeliling garis lurus tersebut (tidak terpancar jauh dari garis lurus). Dengan demikian, bisa dikatakan bahwa persyaratan normalitas bisa bisa dipenuhi.

Uji multikolinieritas dimaksudkan untuk mengetahui apakah terjadi korelasi atau hubungan linier yang kuat diantara variabel bebas dalam model persamaan regresi ganda. Model regresi yang baik seharusnya tidak terjadi gejala multikolinieritas dalam model didasarkan pada nilai tolerance dan nilai VIF. Dari hasil komputasi data penelitian dengan menggunakan SPSS version 23 dapat diperoleh masing-masing nilai tolerance dan nilai VIF sebagaimana terlihat pada table di bawah ini:

Tabel 6. Uji Variance Inflation Factor \& Tolerance

\begin{tabular}{|c|c|c|c|}
\hline \multirow{2}{*}{\multicolumn{2}{|c|}{ Model }} & \multicolumn{2}{|c|}{$\begin{array}{l}\text { Collinearity } \\
\text { Statistics }\end{array}$} \\
\hline & & Tolerance & VIF \\
\hline \multirow{6}{*}{1} & (Constant) & & \\
\hline & Pendapatan Premi & 199 & 5,020 \\
\hline & Rasio Hasil &, 812 & 1,232 \\
\hline & Investasi & & \\
\hline & Laba &, 581 & 1,721 \\
\hline & Klaim & ,249 & 4,012 \\
\hline
\end{tabular}

a. Dependent Variable : Risk Based Capital

Dari tabel uji VIF dan tolerance diketahui bahwa setiap variabel bebas mempunyai nilai VIF lebih kecil dari 10 dan nilai tolerance lebih besar 0,10 sehingga dapat ditarik kesimpulan bahwa model yang dihasilkan terbebas dari gejala multikolinieritas.

Uji heteroskedastisitas dilakukan untuk mengetahui apakah model regresi terjadi ketidaksamaan varians dari residual satu pengamatan ke pengamatan yang lain. Pengujian heterokedastisitas dalam penelitian ini menggunakan diagram pencar (scatterplot). Berikut diagram pencar hasil uji heteroskedastisitas.

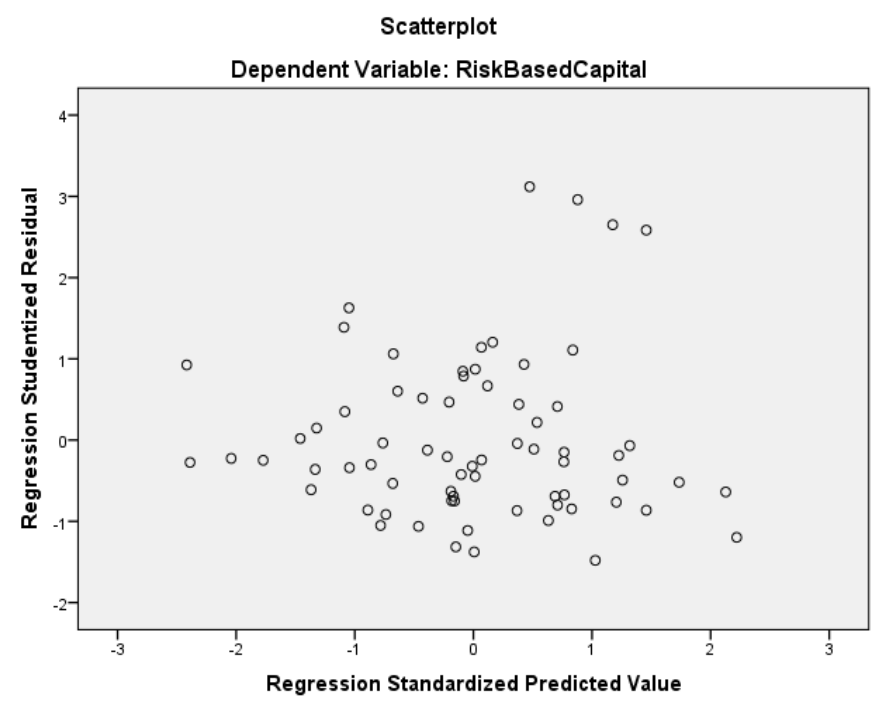

Gambar 1. Hasil Uji Scatterplot

Berdasarkan gambar diatas dapat terlihat sebaran titik-titik pada diagram tidak menunjukkan membentuk suatu pola tertentu serta titik-titik menyebar diatas dan dibawah angka 0 pada sumbu Y. Dengan demikian dapat dikatakan bahwa regresi tidak mengalami gangguan heteroskedastisitas sehingga model regresi tersebut layak dipakai untuk memprediksi risk based capital .

Uji autokorelasi bertujuan menguji apakah dalam suatu model regresi linear ada korelasi antara kesalahan pengganggu pada periode $\mathrm{t}$ dengan kesalahan pada periode t-1 (sebelumnya). Jika terjadi korelasi, maka dinamakan ada problem autokorelasi. Adapaun cara yang digunakan oleh peneliti untuk mendeteksi ada atau tidaknya yaitu dengan menggunakan uji Durbin-Watson (DW-test). Berdasarkan data yang telah diolah dengan SPSS Vol. 23, maka didapat hasil uji autokorelasi , sebagai berikut:

Tabel 7. Uji Autokorelasi

Model Summary ${ }^{b}$

\begin{tabular}{rlrrrr}
\hline Model & $\mathrm{R}$ & R Square & Adjusted R Square & Std. Error of the Estimate & Durbin-Watson \\
\hline 1 &, $420^{\mathrm{a}}$ &, 177 &, 126 &, 87758 & 1,806 \\
\hline
\end{tabular}


a. Predictors: (Constant), Klaim, Rasio Hasil Investasi, Laba, Pendapatan Premi.

b. Dependent Variable: Risk Based Capital.

Pada tabel diatas terlihat bahwa uji autokorelasi diatas dapat diketahui nilai DW (Durbin-Watson) yang dihasilkan dari model regresi adalah sebesar 1,892. Sedangkan dari tabel DW dengan signifikansi 0,05 dan jumlah data $(\mathrm{n})$ sebesar 70, dan $\mathrm{k}$ adalah 4 (k adalah jumlah variabel independen) diperoleh nilai $d_{L}$ = sebesar 1,494 dan $d_{U}=$ sebesar 1,735. Oleh karena nilai DW 1,892 lebih besar dari batas atas $\left(d_{U}\right)$ 1,735 dan kurang dari $4-1,735$ (4 $\mathrm{d}_{\mathrm{U}}$ ), maka dapat disimpulkan bahwa tidak ada autokorelasi positif atau negatif dengan kata lain $\mathrm{H}_{0}$ diterima.

Penelitian ini menggunakan metode multiple regression (regresi berganda) dengan metode Ordinal Least Square (OLS). Metode ini digunakan untuk mengetahui apakah ada pengaruh variabel independen (pendapatan premi, rasio hasil investasi, laba, dan klaim) terhadap variabel dependen (risk based capital).

Tabel 8. Koefisien Regresi

\begin{tabular}{|c|c|c|c|c|c|c|}
\hline \multicolumn{7}{|c|}{ Coefficients $^{\mathrm{a}}$} \\
\hline \multirow{2}{*}{\multicolumn{2}{|c|}{ Model }} & \multicolumn{2}{|c|}{ Unstandardized Coefficients } & \multirow{2}{*}{$\begin{array}{c}\begin{array}{c}\text { Standardized } \\
\text { Coefficients }\end{array} \\
\text { Beta } \\
\end{array}$} & \multirow[t]{2}{*}{$\mathrm{t}$} & \multirow[t]{2}{*}{ Sig. } \\
\hline & & $\mathrm{B}$ & Std. Error & & & \\
\hline \multirow{5}{*}{1} & (Constant) & 2,891 & ,321 & & 8,924 &, 000 \\
\hline & Pendapatan Premi & 0,002 & 1,753 & ,324 & 1,287 & ,202 \\
\hline & Rasio Hasil Investasi & 0,009 & 4,579 &, 054 &, 431 & ,004 \\
\hline & Laba & $-9,300$ &, 001 &,- 001 &,- 005 & ,998 \\
\hline & Klaim & $-0,001$ &, 000 &,- 681 & $-3,020$ &, 003 \\
\hline
\end{tabular}

a. Dependent Variable : Risk Based Capital

Pada hasil persamaan regresi ini, $\beta_{0}$ dilambangkan oleh constant. Dan kolom kedua (Coefficient), berisikan nilai koefisien $(\beta)$ masing-masing variabel dalam persamaan regresi. Berdasarkan hasil output didapatkan persamaan regresi yang terbentuk adalah :

$$
\begin{aligned}
\text { Risk Based Capital }= & 2,891+0,002 X_{1}+0,009 \\
& X_{2}-9,300 X_{3}-0,001 X_{4}
\end{aligned}
$$

4) Pengujian Hipotesis

a) Uji Determinasi $\left(\mathrm{R}^{2}\right)$
Uji Koefisien determinasi $\left(\mathrm{R}^{2}\right)$ merupakan sebuah ukuran "Goodness of Fit", untuk melihat seberapa besar proporsi variasi variabel independen secara bersama-sama dalam menjelaskan (mempengaruhi) variabel dependen. Berdasarkan data yang telah diolah dengan menggunakan program SPSS Vo.23 diperoleh hasil koefisien determinasi $\left(\mathrm{R}^{2}\right)$ atau goodness of fit sebagai berikut:

\begin{tabular}{|c|c|c|c|c|c|}
\hline \multicolumn{6}{|c|}{ Model Summary ${ }^{b}$} \\
\hline Model & $\mathrm{R}$ & R Square & Adjusted R Square & Std. Error of the Estimate & Durbin-Watson \\
\hline 1 & $420^{\mathrm{a}}$ & 177 & , 126 & ,87758 & 1,806 \\
\hline
\end{tabular}

Tabel 9. Uji Koefisien Determinasi $\left(\mathrm{R}^{2}\right)$ Perusahaan Asuransi Kerugian

a. Predictors: (Constant), Klaim, Rasio Hasil Investasi, Laba, Pendapatan Premi

b. Dependent Variable: Risk Based Capital 
Dari hasil olah data diatas dapat diketahui nilai $\mathrm{R}^{2}$ sebesar 0,177 dan Adjusted $\mathrm{R}^{2}$ sebesar 0,126 . Oleh karena dalam penelitian ini $\mathrm{k}>1$, maka Adjusted $\mathrm{R}^{2}<\mathrm{R}^{2}$, yang mengimplikasikan bahwa ketika jumlah variabel independen meningkat maka nilai Adjusted $\mathrm{R}^{2}$ akan meningkat kurang dari nilai Unadjusted $\mathrm{R}^{2}$, oleh karena itu maka penulis menggunakan nilai Adjusted $\mathrm{R}^{2}$ yaitu sebesar 0,126 (12,60\%) yang artinya bahwa proporsi variasi variabel risk based capital yang dijelaskan oleh variabel pendapatan premi, rasio hasil investasi, laba dan klaim adalah sebesar $12,60 \%$. Sedangkan sisanya sebesar $87,40 \%$ merupakan proporsi variasi variabel lain yang tidak termasuk dalam model penelitian ini.

Uji t (t-test) digunakan untuk melihat signifikansi pengaruh variabel independen secara individu terhadap variabel dependen, dengan menggunakan uji dua sisi.

Dari output pada tabel uji $\mathrm{t}$ di atas, bahwa terlihat pada kolom $\mathrm{t}$ statistik (pada taraf probabilitas alfa $(\alpha)=0,05 \mathrm{dan} \mathrm{df}=\mathrm{n}-\mathrm{k}$, atau $\mathrm{df}$ $=70-5=65$, maka diperoleh nilai $\mathrm{t}_{\text {tabel }}=1,997$.

Dari hasil uji t (parsial) tersebut dapat diambil kesimpulan sebagai berikut :

1. $\mathrm{H}_{1}$ (Pendapatan Premi) : Pendapatan premi tidak berpengaruh signifikan terhadap risk based capital, hal ini dibuktikan bahwa $\mathrm{t}$ hitung $<\mathrm{t}_{\text {tabel }}(1,287<1,997)$ dengan nilai probabilitas sebesar 0,202 jauh berada diatas 0,05. Maka $\mathrm{H}_{0}$ Diterima $\mathrm{H}_{1}$ Ditolak, bahwa pendapatan premi tidak berpengaruh signifikan dan negatif terhadap risk based capital;

2. $\mathrm{H}_{2}$ (Rasio Hasil Investasi) : Rasio hasil investasi berpengaruh signifikan terhadap risk based capital, hal ini dibuktikan bahwa $\mathrm{t}_{\text {hitung }}>\mathrm{t}_{\text {tabel }}(0,431<1,997)$ dengan nilai probabilitas sebesar 0,004 berada dibawah 0,05. Maka $\mathrm{H}_{0}$ Ditolak $\mathrm{H}_{1}$ Diterima, bahwa rasio hasil investasi berpengaruh signifikan dan positif terhadap risk based capital;

3. $\mathrm{H}_{3}$ (Laba) : Laba tidak berpengaruh signifikan terhadap risk based capital, hal ini dibuktikan bahwa $\mathrm{t}_{\text {hitung }}<\mathrm{t}$ tabel $(-0,005$ $<1,997$ ) dengan nilai probabilitas 0,9882 berada di atas 0,05. Maka $\mathrm{H}_{0}$ Diterima $\mathrm{H}_{1}$ Ditolak, bahwa laba tidak berpengaruh signifikan dan negatif terhadap risk based capital;

4. $\mathrm{H}_{4}$ (Klaim) : Klaim berpengaruh signifikan terhadap risk based capital, hal ini dibuktikan bahwa $\mathrm{t}_{\text {hitung }}<\mathrm{t}_{\text {tabel }}(0,520<$ 1,997 ) dengan nilai probabilitas 0,003 berada di bawah 0,05. Maka $\mathrm{H}_{0}$ Diterima $\mathrm{H}_{1}$ Ditolak, bahwa klaim berpengaruh signifikan dan positif terhadap risk based capital.

Uji pengaruh simultan digunakan untuk mengetahui apakah variabel independen secara bersama-sama atau simultan mempengaruhi variabel dependen. Bila nilai parameter signifikansi regresi $=0$, dengan kata lain tidak terdapat hubungan yang linear atara variabel dependen dengan variabel independen.

Berdasarkan data yang telah diolah dengan program SPSS Vol.23, diperoleh hasil Uji Pengaruh Simultan (F Test) sebagai berikut:

Tabel 10. Uji Pengaruh Simultan (F Test) Perusahaan Asuransi Kerugian

\begin{tabular}{|c|c|c|c|c|c|c|}
\hline \multicolumn{2}{|c|}{ Model } & $\begin{array}{l}\text { Sum of } \\
\text { Squares }\end{array}$ & df & $\begin{array}{l}\text { Mean } \\
\text { Square }\end{array}$ & F & Sig. \\
\hline \multirow{3}{*}{1} & Regression & 10,742 & 4 & 2,686 & 3,487 &, $012^{\mathrm{b}}$ \\
\hline & Residual & 50,059 & 65 & 770 & & \\
\hline & Total & 60,801 & 69 & & & \\
\hline
\end{tabular}

a. Dependent Variable: Risk Based Capital

b. Predictors: (Constant), Klaim, Rasio Hasil Investasi, Laba, Pendapatan Premi

Dari hasil data yang telah diolah pada tabel 4.7 terlihat bahwa pada kolom 5 nilai $\mathrm{F}_{\text {hitung }}$ sebesar 3,487. Sedangkan nilai $\mathrm{F}_{\text {tabel }}$ dapat dilihat pada tabel statistik $\mathrm{F}$ (pada taraf signifikansi alfa $(\alpha)=0,05$ dan derajat bebas $\mathrm{db}_{1}=\mathrm{k}$ dan $\mathrm{db}_{2}=\mathrm{n}$ $-\mathrm{k}-1$ ), atau $\mathrm{db}_{1}=4 \mathrm{dan} \mathrm{db}_{2}=70-4-1=65$, maka diperoleh nilai $\mathrm{F}_{\text {tabel }}=2,513$.

Oleh karena nilai $\mathrm{F}_{\text {hitung }}$ lebih besar daripada $\mathrm{F}_{\text {tabel }}(3,487>2,513)$, maka dapat diambil kesimpulan bahwa pendapatan premi, rasio hasil 
investasi, laba dan klaim secara bersama-sama (simultan) berpengaruh signifikan terhadap variabel risk based capital. Maka Ha5 diterima, bahwa semua pendapatan premi, rasio hasil investasi, laba dan klaim secara bersama-sama (simultan) berpengaruh signifikan terhadap variabel risk based capital.

\section{Simpulan, Keterbatasan, dan Implikasi Hasil Penelitian}

Penelitian ini berupaya untuk menjawab rumusan masalah penelitian, yaitu mengetahui, mempelajari dan menemukan bukti empiris seberapa besar pengaruh pendapatan premi, rasio hasil investasi, laba dan klaim secara parsial maupun secara simultan terhadap risk based capital perusahaan asuransi kerugian swasta nasional yang terdaftar di Otoritas Jasa Keuangan (OJK) yang memiliki ekuitas diatas 500 milyar selama periode tahun 2011 - 2015. Dari hasil pengujian hipotesis dengan menggunakan analisis regresi data panel dengan empat variabel independen (pendapatan premi, rasio hasil investasi, laba, klaim) dan satu variabel dependen (risk based capital), menyatakan sebagai berikut:

Dari hasil analisis dan pembahasan dapat ditarik kesimpulan sebagai berikut:

1. Hasil pengujian dengan menggunakan regresi berganda membuktikan bahwa variabel pendapatan premi tidak berpengaruh signifikan terhadap risk based capital. Dengan demikian menolak hipotesis pertama $\left(\mathrm{H}_{1}\right)$ yang menyatakan bahwa terdapat pengaruh signifikan terhadap risk based capital. Hasil regresi juga menunjukan bahwa pendapatan premi memiliki hubungan positif terhadap risk based capital. Sehingga dapat disimpulkan hasil dalam penelitian ini besar kecilnya suatu pendapatan premi perusahaan yang didapat tidak mempengaruhi tingkat prosentase risk based capital perusahaan asuransi.
2. Hasil pengujian dengan menggunakan regresi berganda membuktikan bahwa variabel rasio hasil investasi berpengaruh signifikan terhadap risk based capital. Dengan demikian menerima hipotesis kedua $\left(\mathrm{H}_{2}\right)$ yang menyatakan bahwa terdapat pengaruh yang signifikan terhadap risk based capital. Hasil penelitian juga menemukan bahwa rasio hasil investasi memiliki hubungan positif terhadap risk based capital. Semakin besar hasil investasi dan total investasi perusahaan asuransi semakin besar tingkat risk based capital perusahaan tersebut.

3. Hasil pengujian dengan menggunakan regresi berganda membuktikan bahwa variabel laba tidak berpengaruh signifikan terhadap risk based capital. Dengan demikian menolak hipotesis ketiga $\left(\mathrm{H}_{3}\right)$ yang menyatakan bahwa terdapat pengaruh yang signifikan terhadap risk based capital. Hasil regresi data panel juga menunjukan adanya hubungan negatif terhadap risk based capital . Laba tidak selalu menjadi tolak ukur untuk menilai tingkat risk based capital, karena naik turunnya laba berbanding terbalik dengan tingkat risk based capital perusahaan.

4. Hasil pengujian dengan menggunakan regresi berganda membuktikan bahwa variabel klaim berpengaruh signifikan terhadap risk based capital. Dengan menolak hipotesis keempat $\left(\mathrm{H}_{4}\right)$ yang menyatakan bahwa terdapat pengaruh signifikan terhadap risk based capital. Hasil regresi juga menemukan adanya hubungan yang negatif antara klaim dengan risk based capital. Dari hasil penelitian ini dapat disimpulkan bahwa besar kecilnya klaim yang dimiliki perusahaan asuransi akan mempengaruhi risk based capital perusahaan.

5. Hasil pengujian dengan menggunakan regresi berganda membuktikan bahwa pendapatan premi, rasio hasil investasi, 
laba, dan klaim secara simultan berpengaruh secara simultan terhadap risk based capital perusahaan asuransi kerugian yang terdaftar di Otoritas Jasa Keuangan selama periode penelitian tahun 2011-2015. Hal ini berarti bahwa faktor fundamental perusahaan yang berasal dari laporan keuangan yang di representasikan oleh pendapatan premi, rasio hasil investasi, laba dan klaim secara bersama-sama memberikan sinyal yang positif untuk memprediksi kesehatan perusahaan asuransi dalam hal ini kinerja perusahaan pada saat ini maupun yang akan datang sehingga menjadi pertimbangan pemangku kepentingan dalam menetapkan keputusan bagi perusahaan asuransi sehingga tingkat kesehatan perusahaan asuransi dalam mengelola risiko dapat dikelola secara baik dengan tingkat solvabilitas perusahaan terjaga.

Dalam penelitian ini penulis menyampaikan bahwa terdapat beberapa keterbatasan, terutama pada hal-hal sebagai berikut:

1. Hasil penelitian ini menyatakan bahwa variabel dependen di pengaruhi oleh variabel independen sebesar $12,60 \%$ dan sisanya sebesar $87,40 \%$ di pengaruhi oleh faktor-faktor lain yang tidak termasuk dalam model penelitian ini, sehingga masih banyak variabel lain yang berpengaruh terhadap risk based capital namun tidak dalam model penelitian ini.

2. Penelitian ini terbatas pada perusahaan asuransi kerugian yang memiliki ekuitas diatas 500 milyar yang terdaftar pada Otoritas Jasa Keuangan, sehingga masih banyak perusahaan asuransi kerugian yang memiliki ekuitas di bawah 500 milyar yang masih harus di teliti yang tidak masuk dalam penelitian ini.

3. Penelitian ini hanya mencakup pada periode penelitian selama 5 tahun yaitu tahun 2011

- 2015 saja, sehingga data penelitian yang diperoleh masih dalam waktu terbatas dan belum dapat digeneralisasi untuk periode yang lebih panjang.

4. Penelitian ini hanya mencakup pada industri asuransi kerugian, sedangkan pada industri asuransi masih ada asuransi jiwa yang sebenarnya menarik untuk diteliti.

Penelitian ini diharapkan dapat berguna untukpengambilankebijakandisektorpemerintah dalam rangka melakukan pengawasan terhadap kesehatan perusahaan asuransi. Sehingga, diharapkan perusahaan asuransi memiliki kekuatan modal yang cukup dan menghindarkan resiko merugikan nasabahnya dalam hal terjadi masalah atau kerugian sebagai akibat dari deviasi dalam pengelolaan kekayaan dan kewajiban.

Pada sektor swasta yaitu perusahaan asuransi penelitian ini diharapkan dapat berguna untuk untuk mengambil keputusan dalam menjaga kesehatan keuangan perusahaan dan pengelolaan risiko yang telah diberikan kepercayaan oleh tertanggung tetapi tanpa mengesampingkan faktor lain yang dapat mempengaruhi stabilitas kelangsungan bisnis perusahaan.

Sedangkan bagi kalangan akademisi diharapkan dapat berguna untuk melakukan penelitian selanjutnya mengenai risk based capital dikarenakan masih terdapat $87,40 \%$ faktor lain yang belum masuk dalam model penelitian ini, sehingga diharapkan bagi peneliti selanjutnya untuk menggali faktor lain secara komprehensif, karena sangat dimungkinkan sekali variabel lain dapat mempengaruhi (menjelaskan) terhadap risk based capital serta menambah sampel dan renteng waktu yang lebih panjang sehingga penelitian berikutnya diharapkan mendapatkan hasil yang lebih baik dan dapat digeneralisasi dalam penelitian sejenis, serta menghasilkan penelitian yang lebih baik.

\section{Daftar Referensi}

Abbas, Salim. 2007. Asuransi \& Manajemen Risiko, Rajawali Pers. Jakarta.

Darmawi, Herman. 2000. Manajemen Asuransi, Bumi Aksara. Jakarta.

Ghozali, Imam, 2016. Aplikasi Analisis Multivariat dengan Program IBM SPSS 
23. Edisi 7, Badan Penerbit Universitas Diponegoro. Semarang.

Gujarati, D.N., 2012. Dasar-dasar Ekonometrika, terjemahan Mangunsong, R.C., Salemba Empat., Buku 2 Edisi 5. Jakarta.

Harahap, Sofyan Syafri. (2007). Teori Akuntansi. Edisi Revisi. Raja Grafindo Persada. Jakarta.

Hartono, Jogiyanto. 2010. Teori Portofolio dan Analisis Investasi. Edisi 7. BPFE. Yogyakarta.

Ikatan Akuntan Indonesia, (2015), Standar Akuntansi Keuangan, PSAK No. 28 Tentang Standar Akuntansi Asuransi Kerugian, Jakarta.

Media Asuransi. 2012.Best Insurance 2012. Edisi 267.

Media Asuransi. 2014.Best Insurance 2014.No. Edisi 279.

Media Asuransi. 2015.Best Insurance 2015.No. Edisi 293.

Media Asuransi. 2016.Best Insurance 2016.No. Edisi 305.

Otoritas Jasa Keuangan. 2014. Perasuransian Indonesia 2014, (online). Jakarta: Otoritas Jasa Keuangan Republik Indonesia. (http://www.ojk.go.id/statistik-2014perasuransian, diakses pada 11 April 2016).

Peraturan Menteri Keuangan No. 53/ PMK.010/2012 tanggal 3 April 2012 Tentang Kesehatan Keuangan Perusahaan Asuransi dan Perusahaan Reasuransi.

Peraturan Ketua Badan Pengawas Pasar Modal No. PER - 08 /BL/2012 Tentang Pedoman Perhitungan Modal Minimum Berbasis Risiko Bagi Perusahaan Asuransi Dan Perusahaan Reasuransi.

Prawoto, Agus. 2003. Hukum Asuransi dan Kesehatan Perusahaan Asuransi Berdasarkan Risk Based Capital, BPFE. Yogyakarta.

Sula, M. 2001. Konsep dan Operasional Asuransi Kerugian, PT.Gema Insan Pers. Jakarta.
Sugiyono. 2009. Metode Penelitian Kuantitatif dan Kualitatif, CV.Alfabeta. Bandung.

Soeisno, Djojosoedarso. 2003. Prinsip-prinsip Manajemen Risiko dan Asuransi. Edisi Revisi. Salemba Empat. Jakarta.

Sensi, Ludovicus. 2006. Memahami Akuntansi Asuransi Kerugian. PT. Prima Mitra Edukarya. Jakarat.

Widarjono, Agus.2013. Ekonometrika Pengantar dan Aplikasinya Disertai Panduan Eviews. UPP STIM YKPN.Yogyakarta.

Astria, Dian. 2009. Analisis Faktor-Faktor Yang Mempengaruhi Tingkat Kesehatan Perusahaan Asuransi ( Studi Kasus PT. Asuransi Takaful Keluarga) E-Journal Manajemen Institute Pertanian Bogor.

Astika, Ida Bagus Putra. 2003. Hubungan Keagenan dan Hukum Besi dalam Manajemen Laba, artikel jurusan Akuntansi, Fakultas Ekonomi Universitas Udayana, Bali.

Budiarjo, Rifki Santoso. 2015. Pengaruh Tingkat Kesehatan Keuangan Perusahaan Asuransi Terhadap Peningkatan Pendapatan Premi (Studi Kasus Pada Perusahaan Asuransi Yang Terdaftar di Bursa Efek Indonesia Tahun 2010-2013) E-Journal Manajemen Universitas Negeri Yoyakarta.

B. Charumathi. 2012. On The Determinants of Profitability of Indian Life Insurer - An Empirical Study, Proceeding of the World Congress On Engineering. London.

Cummins, J. David, Harrington, Scott. E, and Klein, Robert. 1995. Insolvency Experience, Risk-Based Capital and Prompt Corrective Action in Property-Liability Insurance. Journal of Financial Institution Center, (online), (http://fic.wharton.upenn. edu/fic/papers/95/9506.pdf, diakses pada 16 Desember 2014).

Dhaniati, Rina. 2011. Analisis Pengaruh RBC, Rasio Underwriting, Rasio Hasil Investasi, Rasio Penerimaan Premi, dan Rasio Beban Klaim Terhadap Laba Perusahaan Asuransi. 
artikel jurusan Akuntansi, Fakultas Ekonomi Universitas Gunadarma, Jakarta.

Dika, Arrum. 2014. Analisis Faktor-Faktor Yang Mempengaruhi Return on Equity Pada Perusahaan Asuransi Umum.) E-Journal Akuntansi Universitas Diponegoro. Semarang.

Eko Supriyono, Agung.2013.Pengaruh Risk Based Capital Terhadap Profitabilitas Pada Perusahaan Asuransi Syariah (Studi Kasus Pada PT. Asuransi Takaful Umum dan PT.Asuransi Takaful Keluarga Periode 2004-2010) E-Journal Akuntansi Universitas Pendidikan Indonesia.

Eky, Gede et al. 2015. Pengaruh Laba, Underwriting, Hasil Investasi dan Rasio Beban Klaim Terhadap Risk Based Capital (Studi pada perusahaan asuransi yang terdaftar di BEI 2010-2014)" E-Journal S1 Ak Universitas Pendidikan Ganesha Vol.3 No. 1 Tahun 2015.

Fadlin, Aditya R.P \& Rachma Fitrianti. 2013. Analisis Pengaruh Risk Based Capital, Penerimaan Premi, Underwriting dan Beban Klaim Terhadap Profitabilitas, artikel jurusan FISIP, Universitas Indonesia, Jakarta.

Fitriani, A\& Apriani Dorkas R.A. 2009. Tinjauan Empiris Terhadap Kinerja Industri Asuransi Yang Go Public Di Bursa Efek Indonesia. Jurnal Ekonomi dan Bisnis, Vol. XV, No. 2 Grace, Martin, Scott E. Harrington, and R. Klein. (1998). Risk-Based Capital and Solvency Screening: Hypotheses and Empirical Tests. Journal of Banking and Finance.

Hafid, Ibrahim. 2016.Analisis Tata Kelola Keuangan Asuransi Jasa Dalam Menilai Kinerja Operasional Usaha Secara Periodik. Jurnal keuangan dan perbankan Vol.20 No. $1 \mathrm{Hlm} 50.62$.

Jensen, Michael C, Dan W,H,Meckling, 1976.

Theory Of The Firm: Agency Costs And Ownership Structure". Journal of Finance Economics, Vol. 3, No. 4, pp. 305-360.
Kirmizi dan Agus, Susi Surya. 2011. Pengaruh Pertumbuhan Modal dan Aset Terhadap Rasio Risk Based Capital (RBC), Pertumbuhan Premi Neto dan Profitabilitas Perusahaan Asuransi Umum Di Indonesia. Jurnal Pendidikan Ekonomi dan Bisnis, (online), Vol.3, No.1, (http://ejournal. unri.ac.id/index.php/JPEB/article/ viewFile/403/397, diakses pada 11 April 2016).

Marlina, Reni, Dwi Puryanti. 2013. The Influence of Risk Based Capital to Profitability In Jasindo Insurance Company. South East Asia Journal of Contemporary Business, Economic and Law, Vol. 2.

Merawati, Endang Etty. 2002. Penilaian Perusahaan Asuransi Dengan Risk Based Capital dan Early Warning System, artikel jurusan Akuntansi, Fakultas Ekonomi Universitas Pancasila, Jakarta.

Nurfadila, Sindi et al. 2015. Analisis Rasio Keuangan Dan Risk Based Capital Untuk Menilai Kinerja Keuangan Perusahaan Asuransi (Studi pada PT. Asei Reasuransi Indonesia (Persero) Periode 2011-2013)" Jurnal Administrasi Bisnis (JAB)|Vol. 22 No. 1 Mei 2015|

Pitselis, Georgios.(2006). Risk Based Capital, Supervision of Solvency and Cross-Section Effect models. University of Piraeus, Department of Statistics \& Insurance Science.

Soekarno, S \& Azhari, D.A 2009. Analysis of Financial Ratio to Distinguish Indonesia Joint Venture General Insurance Company Performance using Discriminant Analysis. The Asian Journal Of Technology Management. 2 (2) : 100-111.

Supriyono, Agung Eko. 2013. Pengaruh Risk Based Capital terhadap Profitabilitas pada Perushaan Asuransi Syariah: Studi Kasus Pada PT. Asuransi Takaful Umum dan PT. Asuransi Takaful Keluarga Periode 2004-2010. Thesis. Univesitas Pendidikan Indonesia. 
Satria, Salusra, 2004, Pengukuran Kinerja Keuangan Perusahaan Asuransi Kerugian di Indonesia dengan analisis rasio keuangan Early Warning System. Edisi pertama Lembaga Penerbit FE-UI, Jakarta.

Witono, Eka Purnama.2003. Analisis Kinerja Perusahaan-Perusahaan Asuransi Di Indonesia Dengan Metode Risk Based Capital. Jurnal akuntansi Krida WacanaVol. 3 No. 1, Fakultas Ekonomi Universitas Kristen Krida Wacana, Jakarta.
Yuli Asmoro, Kurniawan. 2010. Pengaruh Pendapatan Premi, Rasio Hasil Investasi, dan Klaim terhadap Risk Based Capital. artikel jurusan Akuntansi, Fakultas Ekonomi Universitas Trisakti, Jakarta.

Yuliani. 2014. Peran Dinamika Lingkungan Sebagai Moderasi Pengaruh Likuiditas dan Risk Based Capital Terhadap Kinerja Keuangan Perusahaan Asuransi Umum Indonesia. Forum Manajemen Indonesia, Medan. 